\title{
Small Businesses in Cultural Tourism in a Central European Country
}

\author{
Ladislav Mura \\ Pan-European University in Bratislava, Slovakia \\ Patrik Kajzar
}

School of Business Administration in Karvina, Silesian University, Czech Republic

Received: 7 October 2019. Revision received: 13 October 2019. Accepted: 15 October 2019

\begin{abstract}
The aim of this article is to test the hypotheses whether the selected cultural and historical monuments and cultural events are an inspiration for tourists to visit. Our main objective is to determine whether a statistical relationship can be detected between the number of selected monuments and cultural events in Czech Republic and the number of its visitors. All analyzed data on this cultural destination was obtained from the statistics of NIPOS (The National Information and Consulting Centre for Culture between 2008 - 2017). Historical monuments that charge admission fees were statistically analyzed. SPSS will be used to calculate the correlation coefficient. Based on the results of $\mathrm{H} 1$ verification, there is no statistically significant difference between the number of monuments accessible to visitors for a fee and the average number of visitors per single historical monument. According to $\mathrm{H} 2$ verification, there is no statistically significant difference between the number of cultural events in historical monuments and the number. of visitors attending these cultural events. Cultural monuments and cultural events are one of the alternative motivations to attract tourists to the cities. If there is no improvement in tourism infrastructure, it will be very difficult to attract visitors. Cities also have the task of improving services in the areas of catering, accommodation, transport services and activities for children. The results are mainly relevant for destination management organizations and cultural organizations that can help attract more tourists by using various tools.
\end{abstract}

Key Words: Czech Republic, cultural destinations, cultural monuments and events, small and medium-sized enterprises, statistical analysis heritage, tourism.

JEL Classification: L26, L83, Z32

\section{Introduction}

The tourism industry is dominated by small and medium-sized enterprises. They are often led by entrepreneurs who face the challenge of simultaneously managing business decisions and their own well-being. The competitiveness of tourism destinations often depends on these entrepreneurs and therefore understanding their motivations and work pattern is crucial (Peters, Kallmuenzer and Buhalis, 2019; Rogalska, 2018). Though tourism has become a significant element influencing how people inhabit their world, the dwelling perspective as a conceptual tool has generated little interest amongst scholars 
studying these toured landscapes from a local perspective (Prince, 2018;Alammari,Darougi, Dunay, 2019).

The tourism industry is one of the fastest-growing industries in the world (Ranasinghe, 2019). The rapid growth of digital technology, intensive presence on social media platforms leads to the emergence of online content sharing (people to people), that results in the emergence of sharing economy (Krajcik, Kljucnikov, and Rihova, 2019). Regarding the ridesharing industry Ključnikov, Popesko, and Kloudová, (2019) concluded that real-time ridesharing services dramatically lower the cost of transportation and argued that low digital literacy of the users and providers can make such services infeasible and disadvantageous.

According to Leposa (2019), last year travel and tourism grew by 3.9 percent, exceeding the global GDP growth of 3.2 percent and contributing to a record of $\$ 8.8$ trillion and 319 million jobs to the world economy. The report also found that travel and tourism industry generated 10.4 percent of all global economic activity last year. The industry has been responsible for one in five of all new jobs created worldwide over the last five years It is also the second-fastest-growing sector in the world, compared to healthcare $(+3.1 \%)$, information technology $(+1.7 \%)$ and financial services $(+1.7 \%)$. Only the manufacturing sector, growing by $4 \%$ exceeded the growth of the tourism sector.

Heritage tourism is a motivation to experience the places and activities that authentically represent the stories and people of the past and the present. In tourism sector are many people employed, too. (Adongo, Choe, \& Han, 2017; Pauhofova et al., 2018; Pauhofova, Stehlikova, 2018). Cultural monuments, museums, galleries, and other cultural institutions, as well as cultural events, are an important part of tourism potential. We call them cultural destinations because those interested in cultural tourism often visit them.

The paper is organized as follows: First, we perform a literature review focused on heritage tourism and provide information about small and medium-sized enterprises operating in the tourism industry. This is followed by the presentation of the adopted methodology and the research questions formulated After that, we present and discuss the main results. Finally, the main conclusions are summarized.

\section{Literature review}

This chapter is addressing the issue of culture and tourism; heritage tourism as one of the basic forms of tourism will be presented and the definition of cultural destinations will be provided. Zhang and Smith (2019) defined heritage as either materially based e.g. sites, places or buildings, or as intangible cultural practices that may involve music, traditions, festivals, etc.. According to Seyfi, Hall and Rasoolimanesh, (2019) heritage tourism is a significant element of tourism for many destinations; nevertheless, relatively little is known about the contributing factors that form the overall cultural travel experience. The United Nations Educational, Scientific and Cultural Organization (UNESCO) defines cultural heritage as the legacy of physical artifacts and intangible attributes of a group or society that are inherited from past generations, maintained in the present and bestowed for the benefit of future generations.

Tourism is acknowledged as a vehicle that can help sustain both tangible and intangible elements of Indigenous cultural heritage, including languages, stories, songs, art, dance, hunting methods, rituals, and customs. Often, cultural heritage products developed for tourism promise to provide many socio-economic opportunities for the 
communities involved, however, tourism can also present a challenge as the selfmanagement of Indigenous cultural products and cultural identity can be problematic (Ruhanen and Whitford, p. 179, 2019; Sebestova et al., 2018).

According to Urry (1990), heritage is a broad concept that includes the natural as well as the cultural environment of a community. Two major types of patrimony are identified in heritage studies: the tangible and the intangible. Tangible heritage is typically subdivided into the cultural and the natural. The list of tangible cultural heritage involves the following: historic cities, cultural landscapes, natural sacred sites, underwater cultural heritage, museums' historical monuments, parks, old buildings, archaeological sites, ruins, parks, etc.

Similar to tangible cultural heritage, traditional performing arts as an intangible cultural heritage of humanity are valuable resources for development of heritage tourism of a destination. However, there is very little research done in this area, leaving a blurred understanding of how to commodify and promote traditional performing arts as a heritage product (Io, 2019). Harvey (2001) highlights that monuments, historical buildings or cultural landmarks are also necessary for social life since they construct ideas of individuality and group identity. Heritage tourism is commonly regarded as an activity done by tourists in space where historic artifacts are presented. From its broader meaning, heritage is often associated with 'inheritance' (Yan, 2019; Stankova, Tsvetkov, Ivanova, 2019).

According to Claudia (2019) or Filip, Filipova, L'., Chovanova-Supekova, S. (2016) many international organizations have posited tourism based on cultural heritage as a tool to be deployed toward greater inclusion and socio-economic development. Rural areas are places to be rediscovered based on their traditions, landscapes, gastronomy, and handicraft as a part of the culture.

The development of tourism demand, caused by tourists'awareness, and at the same time demographic changes, accelerates the segmentation and the creation of new types of proposals (Shevyakova, Munsh, and Arystan, 2019; Androniceanu, 2019).Thetypicalculturaltourists are peopleaged $45-60$. Most of them are peoplewithhigherincomes and education willing to spend more money on theirtrips. The trend indicated in theUNWTO documentcanbeseenalso in the Czech Republic.Heritagetourism and activitiesassociatedwithit are the most frequent motive fortravel ofdomestic and foreigntourists. It isconfirmed by theresults of the Czech TourismAuthorityresearch,whichmonitorsbothdomesticand incomingtourism (Zedková and Kajzar, 2013).

It might be well accepted nowadays that intensive competitiveness in terms of both quantity and quality makes it extremely difficult for a firm to differentiate itself from its competitors. Moreover, dynamic business environments (Peracek, Noskova, Mucha, 2017) and increasing customer power have pushed firms toward a customer-focused strategy, especially using new technology to build relationships with the customer (Minh and Huu, 2016)

While some tourists are interested in accessing authentic culture, other aspects, such as enjoyment and relaxation receive a higher priority. Many visitors are concerned about over-commercialization, superficial cultural portrayals and a high concentration of tourist facilities. It is argued that increasing the level of authenticity may be a strategy to promote the overall attractiveness of the site (Yang, 2018; Čulková, Weiss, 2016).

The tourism sector is based on cooperation. As a specific service industry, tourism is fragmented both geographically and in business terms. The dominance of micro and small companies in a multi-sector market creates a need for cooperation (Borodako \& 
Kožić 2016). SMEs are the major sector of every country. The sector has an important contribution to the Gross Domestic Product (GDP) of every country. Increase in GDP results in improvement of the economic growth (Haseeb, et. al, 2017). The accelerated pace of GDP growth with the simultaneous growth of the state budget deficit is an indicator of its effective management, as economic growth allows new, unplanned revenues and other incomes that will reduce the size of the gap between revenues and expenditures of the budget (Shkarlet, et al., 2019).

The quality of the business environment plays an important role (Belas, et al., 2019). The complex characteristics of the factors that determine the quality of the business environment are presented for example by Kozubíková and Kotasková, (2019). Larger companies belonging to the SME segment were more innovative, more active and more autonomous in comparison to microenterprises (Belas and Sopkova, 2016; Koval'ová et al., 2018; Chkalova et al., 2019).

Tourism is closely connected to those enterprises that provide accommodation, food, beverage service, transportation, and different administration services for visitors from all over the world. (Mura and Kajzar, 2018). Small and medium-sized enterprises not only face strong competition but have many new opportunities for growth as well (Cepel, et al., 2018).

Tourism is not the only sector that has an economic effect, but it is also a tool that procures interaction between societies. According to Androniceanu (2017, p.61) in a complex and dynamic business environment, managers widely appeal to modern methods and techniques that would help them cope with the competition and offer their customers new, attractive, good quality products and services at competitive prices. In this context, total quality management is a viable and sustainable option that can systematically contribute to the consolidation of the capacity of organizations.

Tourism is a mind-opening experience, which teaches people that the world is not made up of a single model of living, but other models of living exist as well (Wintersteiner $\&$ Wohlmuther, 2014). Many studies have demonstrated that this experience changes the attitudes of people (Çelik, 2019). In order to remain competitive, firms need to build and enhance customer relationships by delivering value, which can't be satisfied with the core product alone (Sarwari, 2017; Vetrakova, Al Khouri, 2017; Kubala, Vetrakova, 2018).

According to Zedeková and Kajzar (2013), cultural tourism is very closely linked to the landscape. In the Czech Republic, it is distinctly evident since the location of historical monuments in diverse Czech landscapes completes the character of the whole cultural heritage. Towns and cities can be regarded as the most typical cultural tourist destinations. Many historical towns in the Czech Republic are popular destinations for tourists' trips, thanks to their cultural potential (Kurowska-Pysz, et al., 2018; DackoPikiewicz, 2019). To complement the range of cultural institutions, the program focused centers are established. They are educational and educational-entertainment centers that combine elements of education and entertainment. Standard museums, libraries, and tourist centers can also provide the same function.

Participation in specific cultural events is frequently the motivation for cultural tourists to travel. They can visit exhibitions, music festivals, theatre performances, etc..

\section{Methods}

This article aims to test the hypotheses that cultural, historical monuments and cultural events are an important motive for tourist trips. We would like to prop theoretical 
information about the specific motives of cultural tourists to visit cultural destinations through the results of the following analysis. Therefore, we have set two null hypotheses. Correlation analysis is used to test the hypotheses which will be accepted or rejected.

Hypothesis 1: There is no correlation between the number of cultural and historical monuments and the number of visitors in the Czech Republic.

Hypothesis 2: There is no correlation between the number of cultural events organized in the Czech Republic and the number of their visitors.

The main objective of this study is to confirm the statistical relationship between the number of selected monuments and cultural events in the Czech Republic and the number of visitors. We applied the correlation analysis to confirm this relationship and used SPSS to calculate the correlation coefficient.

The following research methods were used: descriptive statistics, graphs were used to evaluate the data obtained, analysis, comparison, synthesis, induction, and deduction.

Correlation analysis is used to explain the relationship between the data in cases where we have random variables and we are unable to determine which of them are dependent and independent. Correlation analysis clarifies the direction of the dependence; sometimes the direction can be double-sided. If we have $n$ observed pairs of values of two variables, we consider them as two-dimensional random variables and we look for a suitable two-dimensional probabilistic model. In the case of $n$ observed trios, quaternions, etc. of values then we look for the three-dimensional, four-dimensional, etc. probabilistic model.

For the two-dimensional probabilistic model, we have $n$ pairs of values $X_{i}$ and $Y_{i}$, where $i=1,2, \ldots n$ and we are especially interested in the value of the correlation coefficient, which explains the strength of linear dependence of examined variables. The correlation coefficient is denoted $\rho$, and in practice, we calculate its point estimate, a sample correlation coefficient $(r)$ :

$$
r=\frac{n \sum x_{i} y_{i}-\sum x_{i} \sum y_{i}}{\sqrt{\left[n \sum x_{i}^{2}-\left(\sum x_{i}\right)^{2}\right]\left[n \sum y_{i}^{2}-\left(\sum y_{i}\right)^{2}\right]}} .
$$

The correlation coefficient measures the tightness of the dependence of variables $x_{i}$ and $Y_{i}$ and takes the value in the interval $[-1,1]$. If the value of one variable and also the value of the second variable increases, a direct linear dependence is detected and the correlation coefficient reaches a positive value that closes to 1 . If an increase in value of one variable results in decrease in value of second variable, the correlation coefficient is close to -1 . If the correlation coefficient reaches the value 0 , there is no linear dependence between the variables.

Hypothesis 0 and an alternative hypothesis is formulated to be tested. The value of the test criterion and the critical value of the student's distribution are calculated. The comparison of obtained results will show whether dependence between the variables exists or not. follows:

The steps of the statistical significance test of the correlation coefficient are as

1. $H_{0}: \rho=0$.

$H_{1}: \rho \neq 0$.

The hypothesis $H_{0}$ assumes that the correlation coefficient is not statistically significant, and therefore there is no dependence between the examined variables. Against this hypothesis, the alternative hypothesis $H_{l}$ is laid, which assumes the opposite. 
Pearson's correlation coefficient measures the statistical relationship or association between two continuous variables. It is known as the best method of measuring the association between variables of interest since it is based on the method of co-variance. It gives information about the magnitude of the association or correlation as well as the direction of the relationship.

All analyzed data on this cultural destination was drawn from the statistics of NIPOS - The National Information and Consulting Centre for Culture between 2008 2017. Historical monuments that charge admission fees were statistically analyzed. In our analysis, the cultural monuments include castles, chateaus, churches, cathedrals, towers, ruins, mills, etc., which are available to visitors for admission and which are administered by the National Heritage Institute, cities, and municipalities, churches, private entities, foundations, associations, etc. Monuments managed by museums and galleries are not included. Cultural events can be defined as exhibitions, concerts, dramatic performances, folklore events, and festivals

\section{Results}

As we have already indicated, our goal is to determine the existence of dependence or independence between the number of selected cultural monuments, events in the Czech Republic and the number of their visitors. All analyzed data on these cultural destinations was obtained from the statistics of NIPOS - The National Information and Consulting Centre for Culture between 2008 - 2017.

The cultural monuments of the Czech Republic have protected properties (both real and movable properties) designated by the Ministry of Culture of the Czech Republic. Cultural monuments that constitute the most important part of the Czech cultural heritage may be declared national cultural monuments.

In this paper historical monuments that charge admission fees were statistically monitored. These include fortified castles, castles, cloisters, churches, ruins, mills, towers, etc.. Twelve historical monuments in the Czech Republic are included in the UNESCO World Heritage List (2017): Historic Centre of Český Krumlov (1992); Historic Centre of Prague (1992); Historic Centre of Telč (1992); Pilgrimage Church of St John of Nepomuk at Zelená Hora (1994); Kutná Hora: Historical Town Centre with the Church of St Barbara and the Cathedral of Our Lady at Sedlec (1995); Lednice-Valtice Cultural Landscape (1996); Gardens and Castle at Kroměřǐž (1998); Holašovice Historical Village Reservation (1998); Litomyšl Castle (1999); Holy Trinity Column in Olomouc (2000); Tugendhat Villa in Brno (2001); Jewish Quarter and St Procopius' Basilica in Třebíč (2003) (NIPOS ,2019).

In 2019, two new UNESCO World Heritage Sites were added to the list, increasing their number in the country to 14 . The World Heritage Committee at its meeting in Baku decided to inscribe the Erzgebirge / Krušnohoří Mining Region and the Landscape for Breeding and Training of Ceremonial Carriage Horses at Kladruby nad Labem. They are the first new sites in the Czech Republic since 2003 (Johnston, 2019).

Graph 1 shows the monuments accessible to visitors for a fee between 2017 2008, from a total of 318 monitored sites in 2017 to 277 monuments in 2008.

Graph 2 shows the average number of visitors per single historical monument between 2017 - 2008 in the Czech Republic. On the graph you can see the highest averages in 2017 and 2016; 44492 and 44745 tourists, compared to the number of visitors in 2013. Only 35937 tourists visited the aforementioned monuments in 2013. 
Graph 1 Monuments accessible to visitors for an admission fee

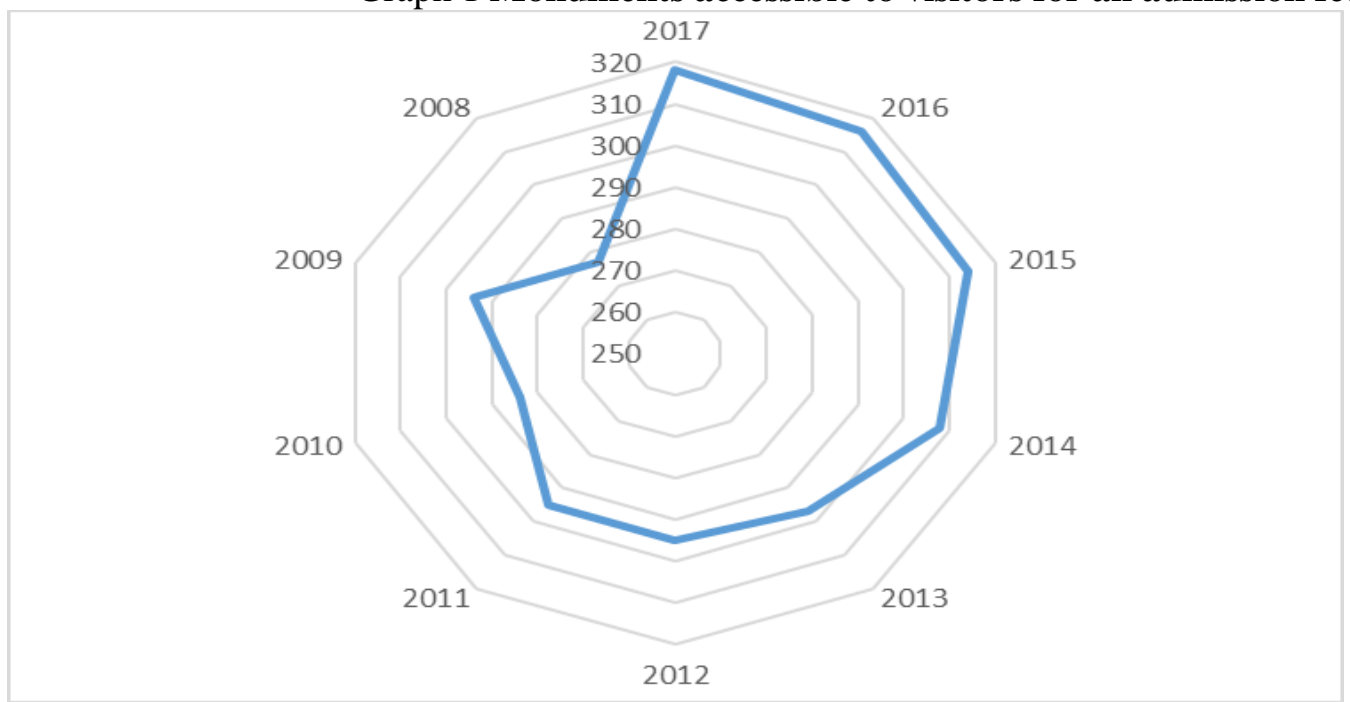

Source: own editing

Graph 2 The average number of visitors per single historical monument

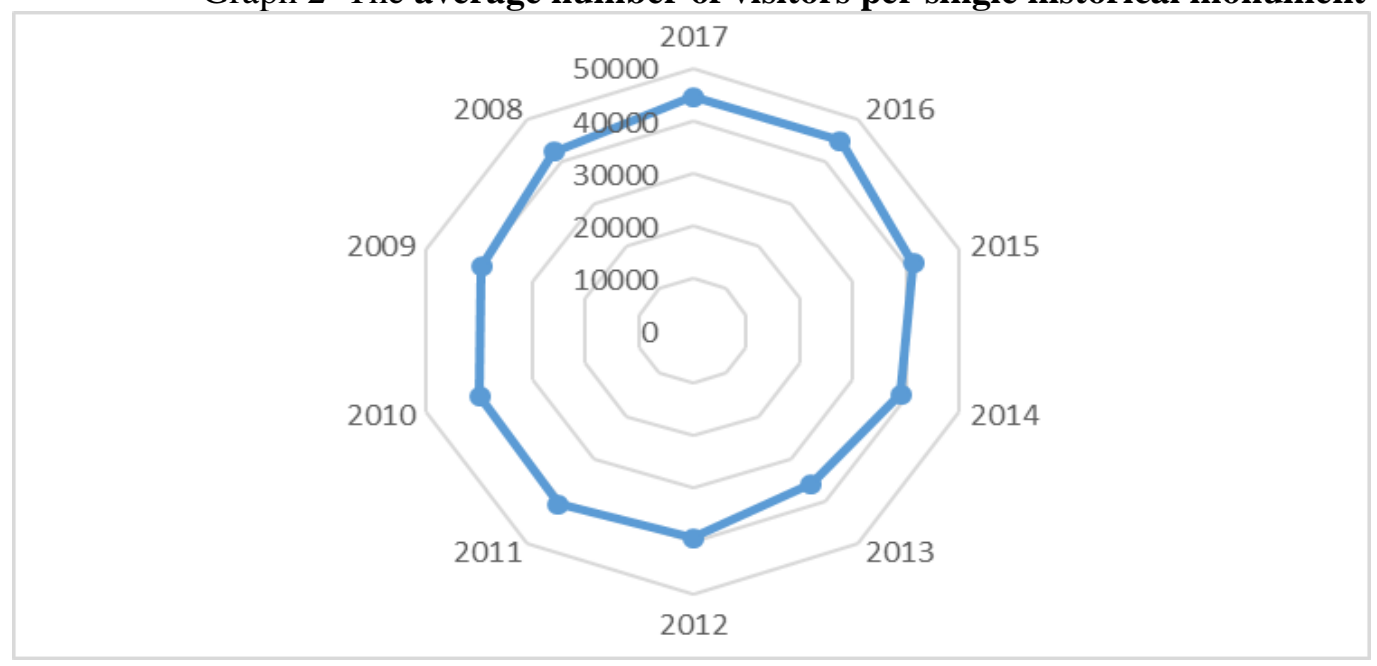

Source: own editing

Graph 3 focuses on cultural events organized in historical monuments. According to graph 3, the most cultural events took place in 2008, altogether 22014 events were organized. There were only 12905 cultural events organized in 2014. Detailed information you can get from the graph below. 
Graph 3 The number of cultural events organized in historical monuments

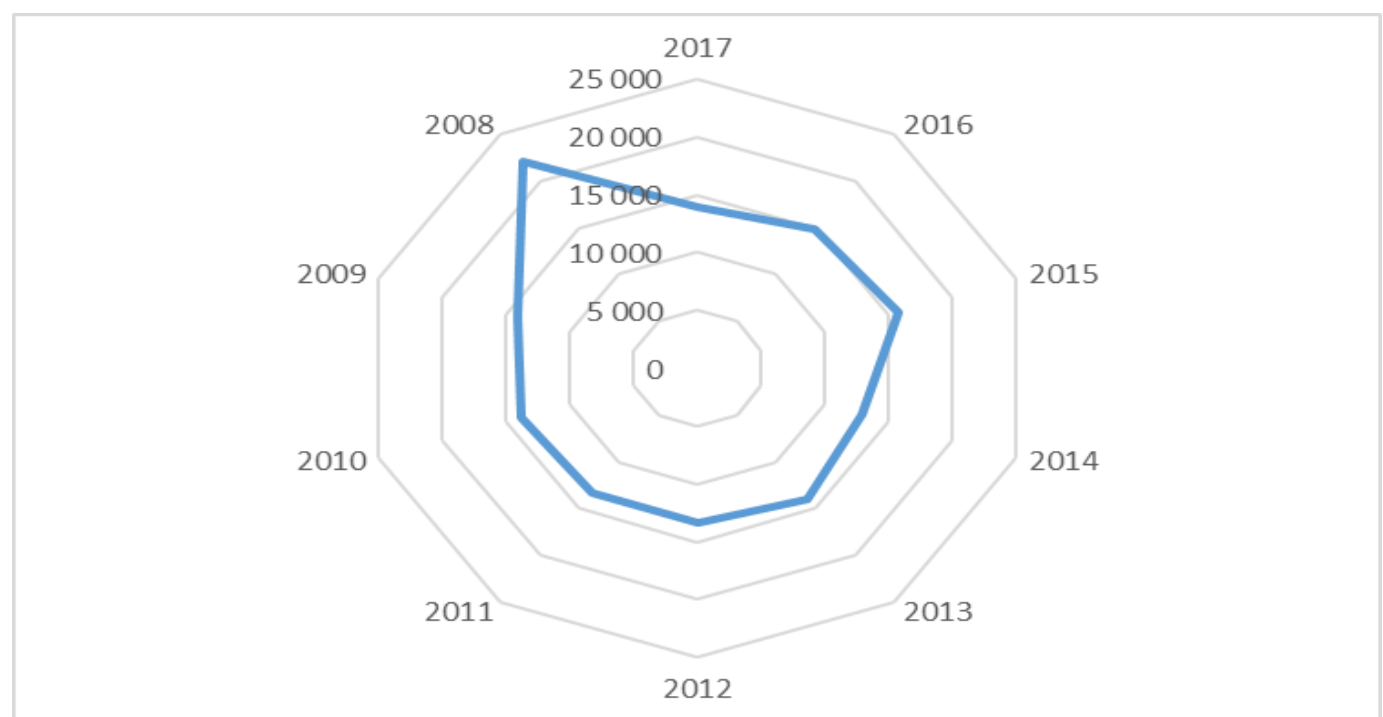

Source: own editing

Graph 4 presents the number of visitors attending cultural events between the years 2017 - 2008. The highest number of visitors (4 969 831) attending cultural events was reached in 2009. In 2017 a total of 4183776 tourists attended 13393 cultural events.

Graph 4 The number of visitors attending cultural events

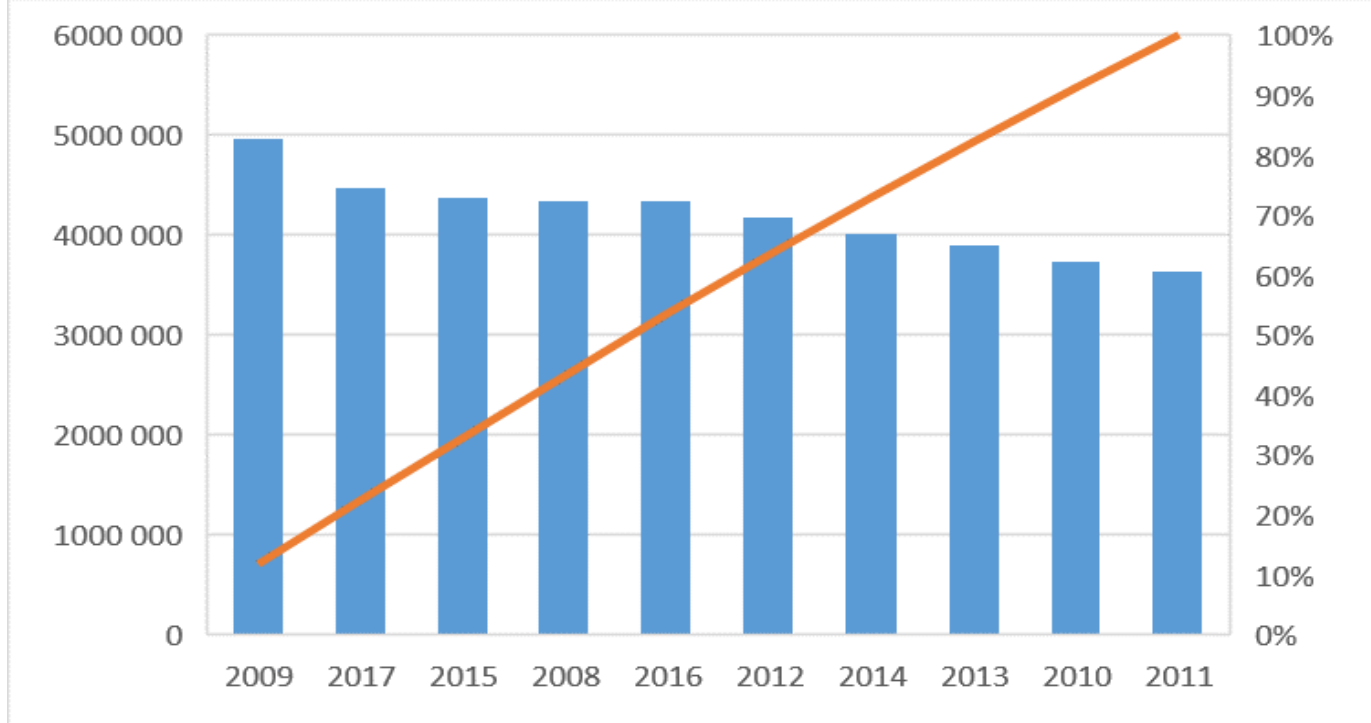

Source: own editing

A correlation analysis was used to process the obtained results. First, we calculated the value of the correlation coefficient, then tested the statistical significance of the correlation coefficient at a significance level of 0,05 . The results of the analysis show that with a probability of $95 \%$ between the studied variables are either confirmed or rejected. The results of the analysis are summarized in Table 1 and Table 2 below. 
Table 1 Results of correlation analysis between the number of monuments accessible to visitors for admission fee and the average number of visitors per single

\begin{tabular}{|l|l|r|r|}
\hline & \multicolumn{3}{|c|}{ Correlations } \\
\hline & & \multicolumn{1}{c|}{$\begin{array}{c}\text { No of } \\
\text { monuments } \\
\text { accessible to } \\
\text { visitors for a fee }\end{array}$} & $\begin{array}{c}\text { Average No. of } \\
\text { visitors per } \\
\text { single historical } \\
\text { monument }\end{array}$ \\
\hline $\begin{array}{l}\text { No of monuments accessible to } \\
\text { visitors for a fee }\end{array}$ & Pearson Correlation & 1 & 0,412 \\
\hline & Sig. (2-tailed)) & 10 & 0,236 \\
\hline $\begin{array}{l}\text { Average No. of visitors per single } \\
\text { historical monument }\end{array}$ & Pearson Correlation & 0,412 & 10 \\
\hline & Sig. (2-tailed)) & 0,236 & 10 \\
\hline & N & 10 & 1 \\
\hline
\end{tabular}

Source: own editing

$r$ - i.e - is the value of Pearson'., the correlation coefficient. That's the Pearson Correlation table, which in this case is 0.412 .

Pearson's $r$ varies between +1 and -1 , where +1 is a perfect positive correlation, and -1 is a perfect negative correlation. 0 means there is no linear correlation at all. In our table, the value is 0.412 , which indicates a weak positive correlation. If one variable increases in value, the value of the second variable will increase as well. Similarly, if one variable decreases in value, the value of the second variable will decrease as well. This is called a positive correlation.

We're also interested in a 2-tailed significance value. In this case, this value is $0,05<0.236$. We can conclude that there is no statistically significant difference between the number of monuments accessible to visitors for admission fees and the average number of visitors per single historical monument.

Table 2 Results of correlation analysis between the number of cultural events in historical monuments and the number. of visitors attending these cultural events

\begin{tabular}{|l|l|r|r|}
\hline & & $\begin{array}{c}|c| \\
\text { No. of cultural } \\
\text { events in } \\
\text { historical } \\
\text { monuments }\end{array}$ & $\begin{array}{r}\text { No. of visitors } \\
\text { attending these } \\
\text { cultural events }\end{array}$ \\
\hline $\begin{array}{l}\text { No. of cultural events in } \\
\text { historical monuments }\end{array}$ & Pearson Correlation & 1 & 0,260 \\
\hline & Sig. (2-tailed)) & 10 & 0,469 \\
\hline $\begin{array}{l}\text { No. of visitors attending these } \\
\text { cultural events }\end{array}$ & N & Pearson Correlation & 0,260 \\
\hline & Sig. (2-tailed)) & 0,469 & 10 \\
\hline & N & 10 & 10 \\
\hline
\end{tabular}

Source: own editing 
r - i.e - is the value of Pearson'., the correlation coefficient. That's the Pearson Correlation table, which in this case is 0.260 .

Pearson's $r$ varies between +1 and -1 , where +1 is a perfect positive correlation, and -1 is a perfect negative correlation. 0 means there is no linear correlation at all. In our table, the value is 0.260 and indicates a very weak positive correlation.

We're also interested in the value of 2-tailed significance. This value is $0.05<$ 0.469 . We can conclude that there is no statistically significant difference between the number of cultural events in historical monuments and the number of visitors attending these cultural events.

\section{Discussion}

Chapter 4 presents the correlation analysis. Hypothesis 1: There is no correlation between the number of cultural and historical monuments and the number of visitors in the Czech Republic. The value 0.412 in Table 1 indicates a weak positive correlation. When we're interested in a 2 -tailed significance value $(0,05<0.236)$ we can conclude that there is no statistically significant difference between the number of monuments accessible to visitors for admission fee and the average number of visitors per single historical monument.

Hypothesis 2: There is no correlation between the number of cultural events organized in the Czech Republic and the number of their visitors.

The value of 0.260 indicates a very weak positive correlation. When we're interested in a 2 -tailed significance value $(0.05<0.469)$, we can conclude that there is no statistically significant difference between the number of cultural events in historical monuments and the number of visitors attending these cultural events.

Zedková and Kajzar (2013) also addressed the issue of determining dependence or independence between the number of selected cultural destinations in each region of the Czech Republic and the number of their visitors in the year 2011. Noonan and Rizzo (2017) devoted to empirical investigations of the relationships between cultural participation and cultural heritage and tourism offer in terms of diversified directions. The authors of this article agree with Noonan and Rizzo (2017), who emphasize that cultural tourism is more than a built heritage, immovable installations, museums, and other permanent attractions. Richards (2018) focuses on the development of cultural tourism as a field of research over the past decade and tries to identify the major trends and research areas. We must not forget to mention the article of the authors Maráková et al. (2018). The objective of this study is to identify the main factors which motivate the visitors to attend traditional cultural events in Slovakia and to examine their viability as the basis for festival market segmentation.

\section{Conclusion}

The main objective of this study was to determine, whether a statistical relationship between the number of selected monuments and cultural events in the Czech Republic and the number of its visitors exists or not. All analyzed data used in this research was obtained from the statistics of NIPOS - The National Information and Consulting Centre for Culture between 2008 - 2017. 
In this paper, the authors are trying to explain the issue of cultural tourism as one of the most important factors in the development of various regions not only in the Central European Countries. Prague is a good example of one of the most important cultural hubs. In the case of Prague, we can conclude that there is no statistically significant difference between the number of monuments accessible to visitors for admission fees and the average number of visitors per single historical monument. The same result is valid also for the second question, where is no statistically significant difference between the number of cultural events in historical monuments and the number of visitors attending these cultural events.

Cultural monuments and cultural events are some of the alternatives to attract tourists to the cities. If there is no improvement in the tourism infrastructure, it will be difficult to increase the number of visitors. Cities also need to improve the tourism-related services e.g. catering, accommodation, transport services, and activities for children. The results obtained are mainly relevant for destination management organizations and cultural organizations that can attract more tourists by using various tools.

The research sample was limited to analyze 10 years in the tourism industry of the Czech Republic. The results of correlation analysis were distorted by involving the cultural attractions visited by tourists in Prague. We would propose to apply this research in the neighboring countries of Czech Republic as well.

\section{Acknowledgment}

This paper was supported by the Ministry of Education, Youth and Sports Czech Republic within the Institutional Support for Long-term Development of a Research Organization in 2019 and by the Ministry of Education, Science, Research and Sports of SR under project VEGA 1/0813/19 Managing the development of innovative and startup forms of businesses in international environment and verification of INMARK concept.

\section{References}

1. Adongo, R., Choe J.Y., \& Han, H. (2017). Tourism in Hoi An, Vietnam: Impacts, perceived benefits, community attachment and support for tourism development. International Journal of Tourism Sciences, 17 (2), 86-106.

2. Alammari, A., Darougi, A.A.M., \& Dunay, A. (2019). Tourism sector in Libya a situation analysis. Acta Oeconomica Universitatis Selye 8 (1), 7 - 20

3. Androniceanu, A. (2019). Social responsibility, an essential strategic option for a sustainable development in the field of bio-economy, Amfiteatru Economic, 21(52), 347-364. DOI: 10.24818/EA/2019/52/503

4. Androniceanu, A. (2017). The three-dimensional approach of Total Quality Management, an essential strategic option for business excellence, Amfiteatru Economic, 19(44), 61-78.

5. Belas, J., Belas, L., Cepel, M., \& Rozsa, Z. (2019). The impact of the public sector on the quality of the business environment in the SME segment. Administratie si Management Public, (32), 18-31, DOI: 10.24818/amp/2019.32-02

6. Belas, J., \& Sopkova, G. (2016). A Model of Entrepreneurial Orientation. Transformation in Business \& Economics, 15, No 2B (38B), 630-645. 
7. Borodako, K., \& Kožić, I., (2016). 'Cooperation patterns in the tourism business: The case of Poland', Prague Economic Papers, 25(2), 160-174. doi: 10.18267/j.pep.552

8. Çelik, S. (2019). Does Tourism Change Tourist Attitudes (Prejudice and Stereotype) towards Local People? Journal of Tourism and Services, 10 (18),3546.

9. Cepel, M., Stasiukynas, A., Kotaskova, A., \& Dvorsky, J. (2018). Business Environment Quality Index in the SME Segment. Journal of Competitiveness, 10 (1), 21 - 40. DOI: 10.7441/joc.2018.02.02

10. Chkalova, O., Efremova, M., Lezhnin, V., Polukhina, A., \&Sheresheva, M. 2019. Innovative mechanism for local tourism system management: a case study, Entrepreneurship and Sustainability Issues 6(4): 2052-2067. https://doi.org/10.9770/jesi.2019.6.4(35)

11. Claudia, T. (2019). Tourism, cultural heritage and local development. Evaluation of the tourism potential of rural villages in the province of Entre Rios, Argentina. Pasos-Revista de Turismo y Patrimonio Cultural, 17(2), doi: 10.25145/j.pasos.2019.17.024

12. Čulková, K., \& Weiss, E. (2016). The application of Isic, Itic and Euro<26 in tourism. Acta Oeconomica Universitatis Selye 5 (2), 56 - 68

13. Dacko-Pikiewicz, Z. (2019). The selected aspects of strategic management in the city divided by the border in the context of the development of the cross-border market of cultural services. Polish Journal of Management Studies, 19(1), 130144, DOI: 10.17512/pjms.2019.19.1.10

14. Filip, S., Filipova, L'., \& Chovanova-Supekova, S. (2016). Migration - a factor of the tourism development in the selected EU countries and the Slovak Republic. Sbornik prispevku z mezinarodni vedecke konference: region v rozvoji spolecnosti 2016, 229-238.

15. Harvey, D.C. (2001). Heritage pasts and heritage presents: Temporality, meaning and the scope of heritage studies. International Journal of Heritage Studies, 7 (4), 319-338.

16. Haseeb, M., Hussai, H. I., Kot, S., Androniceanu, A., \& Jermsittiparsert, K. (2019). Role of Social and Technological Challenges in Achieving a Sustainable Competitive Advantage and Sustainable Business Performance. Sustainability, 11 (14).

17. Io, M. (2019). Understanding the core attractiveness of performing arts heritage to international tourists. Tourism Geographes, 21(4), 687-705. doi: $10.1080 / 14616688.2019 .1571096$

18. Johnston, R. (2019). Two new UNESCO World Heritage Sites named in the Czech Republic. Available at: https://news.expats.cz/weekly-czech-news/twonew-unesco-world-heritage-sites-named-in-the-czech-republic/ (accessed August 2019)

19. Ključnikov, A., Popesko, B., \& Kloudová, J. (2019). Economics of the international ridesharing services - a trap for amateurs, Entrepreneurship And Sustainability Issues, 6(3):, 1072-1081. http://doi.org/10.9770/jesi.2019.6.3(8)

20. Koval'ová, M., Hvolková, L., Klement, L., Klementová, V. 2018. Innovation strategies in the Slovak enterprises. Acta Oeconomica Universitatis Selye 7 (1), $79-89$ 
21. Kozubikova, L., \& Kotaskova, A. (2019). The Impact of Technological Factors on the Quality of the Business Environment. Transformation in Business \& Economics, 18 (1), 95-108.

22. Krajcik, V., Kljucnikov, A., \& Rihova, E. (2019). Innovative Sharing Economy's Business Models in Tourism: Case of Airbnb in Prague. Marketing and Management of Innovations, 2, 108-117. http://doi.org/10.21272/mmi.2019.2-10

23. Kubala, J., \& Vetrakova, M. (2018). Reasons of the employees' stabilization in hotels in Slovakia. Acta Oeconomica Universitatis Selye 6 (2), 90 - 100

24. Kurowska-Pysz, J., Szczepańska-Woszczyna, K., Štverková, H., \& Kašík, J. (2018). The catalysts of cross-border cooperation development in Euroregions. Polish Journal of Management Studies, 18(1), 180-193. DOI: 10.17512/pjms.2018.18.1.14

25. Leposa, A. (2019). Stats: Travel Industry Second-Fastest Growing Sector In The World. Available at: https://www.travelagentcentral.com/running-yourbusiness/stats-travel-industry-second-fastest-growing-sector-world (accessed June 2019)

26. Maráková, V., Ďad’o, J., Táborecká-Petrovičová, J., \& Rajic, T. (2018). Visitors' Motivation for Attending Traditional Cultural Events as the Basis for Market Segmentation: Evidence from Slovakia. Acta Universitatis Agriculturae et Silviculturae Mendelianae Brunensis, 66(2), 543 - 551.

27. Minh, N. V., \& Huu, N. H. (2016). The Relationship between Service Quality, Customer Satisfaction and Customer Loyalty: An Investigation in Vietnamese Retail Banking Sector. Journal of Competitiveness, 8 (2), 103 - 116.

28. Mura, L., \& Kajzar, P. (2019). Entrepreneurship in Tourism Sector in Central European Country: Hospitality Trends in the Czech Republic in 2007 - 2016. Journal of Environmental Management and Tourism, 9(6) 1351-1360. doi: https://doi.org/10.14505//jemt.v9.6(30).25

29. Nipos, (2019). Statistics on culture. Available at: https://statistikakultury.cz/statistic_on_culture/ (accessed August 2019)

30. Noonan, D. S., \& Rizzo, I. (2017). Economics of cultural tourism: issues and perspectives. Journal of Cultural Economics,41 (2), 95 - 107.

31. Pauhofova, I., Stehlikova, B., Kljucnikov, A., \& Androniceanu, A. (2018). Spatial and sectoral conditionality of the average monthly nominal wage in the Slovak republic. Transformations in Business \& Economics 17 (3), 155-168

32. Pauhofova, I., \& Stehlikova, B. (2018). Identifying the Relationship between Unemployment and Wage Development in the Slovak Republic. Ekonomicky casopis 66 (5), 503-521

33. Peracek, T., Noskova, M., \& Mucha, B. (2017). Selected issues of Slovak business environment. Economic and social development (esd): Managerial issues in modern business. Book Series: International Scientific Conference on Economic and Social Development, 254-259

34. Peters, M., Kallmuenzer, A., \& Buhalis, D. (2019). Hospitality entrepreneurs managing quality of life and business growth. Journal of Current Issues in Tourism, 22(16), 2014 -2033. doi: 10.1080/13683500.2018.1437122

35. Prince, S. (2018). Dwelling in the tourist landscape: Embodiment and everyday life amongst the craft-artists of Bornholm. Tourist Studies, 18(1), 63-82. 
36. Ranasinghe, R. (2019). Antecedents of Job Performance of Tourism Graduates: Evidence from State University-Graduated Employees in Sri Lanka. Journal of Tourism and Services, 10(18), 16-34.

37. Richards, G. (2018). Cultural Tourism: A review of recent research and trends. Journal of Hospitality and Tourism Management, 36, 12-21. doi: 10.1016/j.jhtm.2018.03.005

38. Rogalska, E. (2018). Multiple-criteria analysis of regional entrepreneurship conditions in Poland. Equilibrium. Quarterly Journal of Economics and Economic Policy, 13(4), 707-723. https://doi.org/10.24136/eq.2018.034

39. Ruhanen, L., \& Whitford, M. (2019). Cultural heritage and Indigenous tourism. Journal of Heritage Tourism, 14 (3), 179-191. doi: 10.1080/1743873X.2019.1581788

40. Sarwari, S. (2017). Relationship Marketing Model - The Practice of Relationship between Hoteliers and Loyal Customers of Five Star Hotels in Bangladesh. Journal of Tourism and Service, 8 (15), 27-44. doi 10.29036.2017.8.15.3

41. Sebestova, J., Majerova, I., Szarowska, I. (2018). Indicators for assessing the financial condition and municipality management. Administratie si Management Public, (31), 97-110, DOI: 10.24818/amp/2018.31-07

42. Shevyakova, A., Munsh, E., \& Arystan, M. 2019. Towards diversification of the economy of Kazakhstan via information support for the tourism industry, Insights into Regional Development 1(2): 129-137. https://doi.org/10.9770/ird.2019.1.2(5)

43. Seyfi, S., Hall, C.M., \& Rasoolimanesh, S. M. (2019) Exploring memorable cultural tourism experiences. Journal of Heritage Tourism. doi: 10.1080/1743873X.2019.1639717

44. Shkarlet, S., Dubyna, M., Hrubliak, O., \& Zhavoronok, A. (2019). Theoretical and applied provisions of the research of the state budget deficit in the countries of Central and Eastern Europe. Administratie si Management Public, (32), pp. 120-138. DOI: 10.24818/amp/2019.32-09.

45. Stankova, M., Tsvetkov, T., \& Ivanova, L. (2019). Tourist development between security and terrorism: empirical evidence from Europe and the United States. Oeconomia Copernicana, 10(2), 219-237. https://doi.org/10.24136/oc.2019.011

46. Vetrakova, M., \& Al Khouri, B. (2017). Managerial work effectiveness assessment in the hotel company. Topical issues of tourism: tourism as a crossroads of knowledge, 397-407

47. Yan, H. (2019). Cultural Heritage Tourism: Five Steps for Success and Sustainability. Tourism Management, $\quad 70, \quad$ 153-154. doi:10.1016/j.tourman.2018.08.007

48. Yan, L. (2018). Cultural Tourism in a Replicated Old Town: Tourists' Views. Tourism Planning \& Development, 16 (1). 93-111. doi: $10.1080 / 21568316.2018 .1470998$

49. Zhang, R. R., \& Smith, L. (2019). Bonding and dissonance: Rethinking the Interrelations Among Stakeholders in Heritage Tourism. Tourism Management, 74, 212-223. doi: 10.1016/j.tourman.2019.03.004

50. Zedková, A. \& Kajzar, P. (2013). Cultural destinations as one of the most important generators of tourism. Scientific papers of the University of Pardubice. Series D, Faculty of Economics and Administration. 29 (4), 191-202. 


\section{Brief description of Authors:}

assoc. prof. PhDr. Ing. Ladislav Mura, Ph.D.

Head of Department

Department of International Entrepreneurship

Faculty of Economics and Business

Pan-European University in Bratislava

Tematínska 10

85105 Bratislava, Slovakia

Ladislav Mura works as an Associate Professor at the Faculty of Economics and Business of the Pan-European University in Bratislava at the Department of International Entrepreneurship. He is a Slovak economist and expert on small and medium enterprises.

\section{Ing. Patrik Kajzar, Ph.D.}

Department of Tourism and Leisure Activities

Silesian University, School of Business Administration in Karvina

Univerzitni namesti 1934/3, 73340 Karvina, Czech Republic

kajzar@opf.slu.cz

Patrik Kajzar works as an Assistant Professor at SU SBA, Department of Tourism and Leisure Activities and specializes in tourism, hospitality, travel, and human resources management in tourism. 